\title{
The Woolsack and the Winding Stair
}

\author{
C. G. Hall* \\ Lives of the Lord Chancellors 1940-1970 \\ R. F. V. Heuston \\ [Oxford: Clarendon Press, 1987.253pp. Hardback £25.00]
}

Isummon to the winding ancient stair;
Set all your mind upon the steep ascent,
Upon the broken, crumbling battlement,
Upon the breathless starlit air,
Upon the star that marks the hidden pole...'

Professor Heuston has propelled six more Lord Chancellors into legal history. His tally is now 18. Campbell's was upwards of $110 .^{2}$ It was well nigh a quarter of a century ago when were were treated (at 63 s!) to Heuston's first volume ${ }^{3}$ whose subjects' tenures of the office straddled the twilight of Victoria's reign and ended, with Lord Caldecote, two weeks before the evacuation of Dunkirk. The present volume spans the thirty year period to 1970 , from Simon to Gardiner who providentially still lives. Would the latter agree, one wonders, with Baron Lyndhurst that Heuston, like Campbell, has added another terror to death? Lyndhurst had then been assured that he had not been included in Campbell's Lives, redolent as they are generally reckoned to be with misrepresentation, practised venom, mischief but with much fun besides. The present Lord Hailsham cannot be unhappy that for the present no-one has recorded his notable achievements; that, at least, is the sense of his own review of Heuston's work. ${ }^{4}$ But fortune confounded Lyndhurst from the grave, for Campbell added another volume to his series, published after his death, of his contemporaries Lyndhurst and Brougham, and their accounts are remarkable for even greater mischief and

\footnotetext{
* Senior Lecturer in Law, University of Buckingham.

1. W. B. Yeats, "A Dialogue of Self and Soul" from The Winding Slair.

2. John, Lord Cambell, Lives of the Lord Chancellors and Keepers of the Great Seal from the Earliest Times (1845).

3. R. F. V. Heuston, Lives of the Lord Chancellors 1885-1940 (1964).

4. Sunday Telegraph, 19 July 1987. Doubtless Lord Elwyn-Jones would also agree.
} 
inaccuracy. Thanks to Atlay in his The Victorian Chancellors, ${ }^{5}$ and others, ${ }^{6}$ the lives of Brougham and Lyndhurst were re-written, the record straightened, and the majestic chronicle of the Keepers of the Great Seal, these chief "planets of the kingdom", was taken to 1885 and a little beyond. Enter Professor Heuston. He now is assured of his place in history; for whatever his future designs he has ensured that someone will retrieve the baton where he has left it and continue this biographical pageant of the Lord High Chancellors which begins, thanks to Campbell, when men still revered Odin, the Raven, the One-Eyed, and rattled their runes.

Heuston has no obvious grand design other than to "carry on". His object, as he tells us in his Preface, is "to depict the Lord Chancellors ... in their legal, polical and personal lives." But to "depict" exactly how? As camera, caricature or cartoon? In oils or watercolour? As impressionist or pointillist? In monochrome or glorious technicolour? The Preface of the earlier volume is a little more enlightening for Campbell's industry and talent are duly noted and Heuston would "indeed be happy if my work could be compared for felicity in portraiture and literary grace" with that of Atlay.

Campbell aspired to much the same applause and yearned, without apology, for literary fame. But Campbell sought also to distinguish, as Bacon had done, between History and Lives as well as to remark their connections with each other and with the magic of literature. "There is even a sort of romance", he wrote, "belonging to the true tale of many of those who are to be delineated, and the strange vicissitudes of their careers are not exceeded by the fictions of novelists or dramatists." $\mathrm{He}$ thus saw himself as a minstrel rather than a bard whose object was as much as anything else to "amuse" his readers. In this, of course, he was entirely successful for, as Lord Hailsham has remarked, his work became a "permanent best-seller", 8 a fact of which Campbell was not insensible. In the Preface to the second edition in 1846 he reminded his readers "that within a few weeks after its publication [the first edition] was on every table, and almost on every toilette [and] though founded on historical records, and having solid instruction for its object, it has been as generally read as popular works of fiction." If his critics, men, as they say, who have failed in literature and art, crabbed that his style was too familar and colloquial then they only remarked what had been his purpose. For when distilling the philosophy of Bacon, the judgments of Nottingham or the character of Clarendon why should a man adopt the language

5. (1906-1908) in two volumes. See on Atlay, A.W.B. Simpson (ed.), Biographical Dictionayy of the Common Law (1984), pp.20-21. Aday's subjects included both Herschell and Halsbury but he was constrained by the fact that the former had only recently died and the latter still lived. Thus Heuston, supra $\mathrm{n} .3$, reconsiders their 'lives'.

6. Including Sir Charles Wetherell, sometime Attorney-General under Wellington, who also declared, of Campbell, that his "noble and biographical friend ... has added a new terror to death": see his Misrepresentions in Campbell's Lives of Lyndhurst and Brougham (1869), p.3.

7. See Preface to the first edition.

8. Supra n.4. 
of the censor rather than that "which he might with propriety adopt if he were telling it in good society by word of mouth?"

But Campbell had also a much more serious purpose - to trace the history of our constitution and jurisprudence through the biographies of those who kept the King's conscience, his courts and, in earlier times and in his absence, even his kingdom; and their examples would serve "to excite the young student of the law to emulation and industry, and confirm in his mind the liberal and honourable maxims which ought ever to govern the conduct of an English Barrister." 10 Thus Campbell repaid his debt to his profession.

Professer Heuston is wisely more modest than Campbell but it would surely not have been inappropriate for him to have marked the occasion by some reference to the historical and jurisprudential mantle which he has assumed, given its pedigree, rather than to convey merely the idea of a series of potted biographies of famous and influential men in date order. True, there is an excellent Introduction which, though less "readable" than that in the earlier volume, does consider in a sophisticated way the qualifications, appointment, dress, duties and stipend of Lord Chancellors and other related matters; but that is not quite the same thing. Nevertheless, these biographies, of Simon, Jowitt, Simonds, Kilmuir, Dilhorne and Gardiner, do implicitly project a view of History which Campbell and other nineteenth century historians and biographers would have approved. "History", said Carlyle, "is the essence of innumerable biographies." "11 To him, the history of the world was but the biography of great men and though today this dictum may be old fashioned it is not inevitably disreputable provided, at least, that the theory behind it does not amount to purveying tittle-tattle or mere "interests inspired by the eccentricities of individual characters." ${ }^{12}$ Disraeli summarised the idea neatly in the phrase "life without theory". ${ }^{13}$ It is hard to disagree with C. V. Wedgewood that "The behaviour of men as individuals is more interesting ... than their behaviour as groups or classes"; $;{ }^{14}$ and if following the vagaries of fortune upon the lives of great men is indeed a historical fallacy, it is shared also in the legal world by those such as Holdsworth in his Some Makers of English Law. Whether in this second volume Heuston does deal with the lives of great men may be doubted but the fact remains that they did, for good or ill, in their different ways, make "right or wrong for us and for our children". 15

9. Campbell, Preface to the second edition.

10. Preface to the first edition.

11. On History.

12. Acton, Home and Foreign Review (1863), p.219.

13. Contarini Fleming, Ch.23.

14. The King's Peace (1955), p.17.

15. Pollock and Maitland, Histoy of English Law (first edition), Vol. II, p.870, of the men who gathered around Pateshall, Raleigh and Bracton at Westminster. 
The reader will not find in these six vignettes a More, a Bacon, an Eldon, or even a Campbell.

Simon, the man with the "marble smile", who held all the great offices of state, save that of Prime Minister, refused the Woolsack at the age of 42 (in 1915) but accepted it 25 years on and thus combined dazzling legal and political careers. He, perhaps, promises greater prominence in a later age but not, sadly in Heuston's scheme. His "Life" is proscribed with a pauper's share of 25 pages. Of his "remarkable series of magisterial judgments in the House of Lords and the Privy Council"16 Heuston tells us nothing, save that they were "superb", striking in "scale and distinction" and that, in an eloquent phrase, they were delivered "in the English style which is characteristic of Simon - as transparent and cool as a mountain stream."17 There is a very balanced account of Simon's intervention in attempting to secure some modification of Atkin's powerful speech (dissenting) in Liversidge v. Anderson, ${ }^{18}$ an appeal over which Simon did not preside. ${ }^{19}$ To some commentators, his action has been characterised as sinister. ${ }^{20}$ This goes too far. For Simon, in the mildest of terms, merely suggested the removal of the Humpty Dumpty aphorism from Alice Through the Looking Glass which Atkin, in an 11 line paragraph in his 22 page speech, used to illumine why it was that Viscount Maugham and Lords Macmillan, Wright and Romer were proposing, in his view, to stand the English language on its head. This, Simon considered, might cause unnecessary offence to them. ${ }^{21}$ He made no comment upon Atkin's arguably more insidious jibe at his colleagues that the arguments he had heard "might have been addressed acceptably to the Court of King's Bench in the time of Charles I."22 Though a Fellow of All Souls and despite friendships with Goodhart and Winfield, Simon thought that academics as a breed were unfitted for public life since they lived in complete seclusion "and have no contact with the world". ${ }^{23}$ It is hard to imagine Goodhart, at least, as an academic trappist. This Lord Chancellor preferred politics to law but he was not a natural leader. They keynote of his years at the Foreign Office (1931-1935), which witnessed the rise of the dictators, was abstention "from any hint of action" and to "keep out of trouble . . . at all costs"24 and Viscount Simonds remarks in his 'Recollections' that Simon lacked confidence in his own judgment, for ever seeking in deliberative councils a familiar supportive "nod" from colleagues, even junior ones: "In a word he did not lead or

16. Hailsham, supra n.4.

17. At p.58.

18. [1942] A.C. 206, at p.225.

19. See Geoffrey Lewis, Lord Atkin (1983), pp.132-157; R.F.V. Heuston, "Liversidge v. Anderson in Retrospect", 86 L.Q.R. 33 (1970).

20. See, e.g., R. Stevens, Lam and Politics (1979), p.333.

21. This correspondence, inter alia, is quoted fully in Lewis, supra n.19, at pp.139-142. The writer's view is that Atkin 'comes over' as overly didactic and complacent to the possibility of error as if his dignity had been usurped.

22. Supra n.18, at p.244.

23. Quoted Heuston, p.57.

24. Letter to the Prime Minister, 27th July 1934: Heuston, p.50. 
seek to lead." ${ }^{25}$ It is a somewhat touching epilogue to the life of this cold and humourless man who, in Maurice Bowra's words, "longed to be liked" but failed, that he chose to be cremated in his D.C.L. gown.

Jowitt (Joe-itt), Simon's successor, by contrast emerges with a life of 72 pages over five "chapters"; surely, then, an Olympian. But to some he lacked honour and was a "cynical legal careerist" who acted parts, used speech writers and so largely has been quite properly ignored in biographies of the period. He redeems himself, of course, in his keen support for village cricket and by the fact that he is probably the only Lord Chancellor to have known the difference between a Gloucester Old Spot, a Tamworth and a Berkshire; truly, then, a rare breed.

He was also very good at political gaffes, as Heuston amply records. The best known was the curious conversion to Labour on being offered the post of Attorney-General by Ramsay MacDonald (for a long period a personal friend) in 1929 only four days after Jowitt had been elected - as a Liberal - Member for Preston. Parallels were then and subsequently drawn with Yorke, who reneged on his friends to obtain the Great Seal in 1770 but died shattered with remorse three days on, and also with the Vicar of Bray. Jowitt was depicted as a traitor to his class but, having re-submitted himself to the verdict of his constituents later in 1929, at a by-election was returned with a hefty majority. But despite support, inter alios, from Simon, Somervell, Birkett and Buckmaster, the hostility endured particularly from the Bar. ${ }^{26}$ Jowitt's habit of looking one way and rowing another repeated itself two years on. At the General Election which followed the formation of the National Government in 1931 he was unable to win a Combined Universities' seat. But only a few months before he had strenuously argued that university representation should be abolished. The passing years saw no diminution of these powers. He remained Lord Chancellor after Attlee's 1950 election victory and told Shawcross that he was to be Foreign Secretary as successor to Bevin. He was wrong and the incident caused considerable embarrassment. Birkett was also misled over his proposed role at Nuremberg and afterwards was ignored when public honours were distributed for services rendered at that Tribunal. ${ }^{27}$

In many ways, however, Jowitt was a master of political craft, what Heuston refers to as his "detached attitude to political matters" 28 being an obvious virtue; as also was his demeanour in Cabinet where, apparently, he spoke little and was therefore regarded as very valuable ${ }^{29}$ - one of many Heuston insights which betrays a thorough knowledge of the workings of less exalted forums for discussion. We must be grateful that someone has "depicted" Jowitt's Life, which found its "stimulus . . . in the social world where Mayfair and Bloomsbury met". ${ }^{30}$

25. Heuston, p.61.

26. The 'conversion' episode is discussed fully in R.F.V. Heuston, "A Lawyer in Politics: An Episode in the Life of Lord Jowitt", 5 Cambrian Law Review 13 (1974).

27. See H. Montgomery Hyde, Noman Birkett (1964), pp.530-531.

28. At p.114.

29. See Heuston, at p. 98 .

30. Heuston, pp.85-86. 
To Heuston, the hall-mark of a great Lord Chancellor seems to be his reforming zeal and, inter alia, his refusal to be "overwhelmed by the routine duties" of his Office. There is little doubt that Jowitt did preside, for a short period, over a massive programme of law reform, particularly of statute law, even though much of the preparatory work had been forged by others.

Viscount Simonds was not an especially remarkable Lord Chancellor. The Woolsack was his for only three years. He was Churchill's second choice after Asquith who had declined the post on health grounds. The Prime Minister could not remember Simonds, though they had previously met, when the post was offered. And yet even ' $A$ ' level Law students are familiar with his name not least because of his speech in Sham v. D.P.P. ${ }^{31}$ where he declared, echoing Lord Mansfield, ${ }^{32}$ that the judges of the King's Bench are the custos morum of the people; resounding stuff as we all know. A month later Simonds had a stroke but he came back, in the same year, in Scrutton v. Midland Silicones ${ }^{33}$ with undiminished force and paradoxically, but so elegantly, admonished those who in their time have appealed also to Mansfield's spirit in the name of progress: "For me heterodoxy, or, as some might say, heresy, is not the more attractive because it is dignified by the name of reform. Nor will I easily be led by an undiscerning zeal for some abstract kind of justice to ignore our first duty, which is to adminsiter justice according to law." ${ }^{34}$ Fifteen years before he had sat in the appeal in Christie v. Leachinsky ${ }^{35}$ and in his speech had equally demonstrated that the lyrical opulence of language and informal logic may be sublimated, without affectation, even in the law: "Blind, unquestioning obedience is the law of tyrants and of slaves; it does not flourish on English soil." 36 Given Simonds views on privity what would this big, bluff squire, who had obtained a First in Greats and who, as he said, was "not over-awed by the presence of a butler and footman", 37 have made of the reasoning in The Eurymedon ${ }^{38}$ and its spawn The New York Star ${ }^{39}$ With his "neat and tidy mind", in Lord Wilberforce's phrase, ${ }^{40}$ not much one imagines. Of the Lord Chancellors since 1885 only Halsbury (98) and Maugham (92) have lived longer than Simonds (90). It is not surprising, therefore, to find that in his eighties he should have given a passing reflection to his role in history: "I suppose that at some future date there will be a successor to Atlay and Professor Heuston who will write the lives of the Chancellors from 1940 onwards and I daresay he will not find much good to say about me." ${ }^{, 41}$ One is constrained to say that in Heuston's scheme of 17 pages Simonds was right.

31. [1962] A.C. 220, 261 especially at pp.266-269.

32. $R$. v. Delaval (1763) 3 Burr 1434,at pp.1438-1439.

33. [1962] A.C. $446,465$.

34. Ibid., at p.591.

35. [1947] A.C. 573,590 .

36. Ibid., at p.591.

37. Heuston, p. 141.

38. [1975] A.C. 154.

39. [1980] 3 All E.R. 257.

40. Heuston, p. 145.

41. Heuston, p.157. 
In 1942 Churchill made David Maxwell Fyfe Solicitor-General. In 1951 he made him Home Secretary. In that capacity he refused, in the winter of 1952, to recommend the use of the royal prerogative to save from the gallows the 19 year old Derek Bentley who with a 16 year old youth, Christopher Craig, had murdered a police officer. Craig had fired the fatal shot. At the time of the shooting, Bentley had already been in the custody of a courageous policeman, Sergeant Fairfax, who was later to be awarded the George Cross, for some 15 minutes. An illiterate and Grade IV mental defective, Bentley offered no resistance to Fairfax who, despite a wounded arm, still managed to use him as a shield. Craig was determined to avenge his brother who, two days previously, had been sentenced to 12 years for armed robbery. So for him a policeman had to die. He was undoubtedly the ring leader. He had the gun. Bentley had only a knuckle duster. He told Fairfax, "I told the silly . . . not to use the gun." Craig, being under 18, though the perpetrator of the murder could not be hanged. For Bentley the jury recommended mercy but despite demonstrations in the streets, which led to a doubling of the police guard at his flat in Gray's Inn, and a massive condemnation in the country and the House of Commons, Maxwell Fyfe remained unmoved and allowed justice to exact her due. As Heuston remarks, ${ }^{42}$ only Dilhorne would have also displayed a like determination, obstinacy and courage. Simon and Jowitt would have contrived to side-step the issue and run for cover. The Home Secretary had already demonstrated his tenacity at Nuremberg where he was Shawcross' 'junior' but stole the limelight in his cross-examination of Goering who had previously confused and up-staged Justice Jackson, the American prosecutor.

In all his public affairs Maxwell Fyfe was thorough and conscientious. His paper work, though dull, always left his cabinet colleagues ready to move on to the next item. Eighteen months after the Bentley case he succeeded Simonds, as Viscount Kilmuir, on the Woolsack for what was to prove the longest tenure of the Lord Chancellor's officer - eight years - in the period from Simon to Gardiner. That ended abruptly in 1962 with Macmillan's "night of the long knives" which left Kilmuir very offended, even bitter; for he had ever been an intensely loyal and energetic party man with a considerable zest for politics and did not see why he also should be sold as a hostage to Selwyn Lloyd's unhappy fortune.

Sadly his judicial activities were not equally striking. Every law student has suffered the obscurities of D.P.P. v. Smith $;{ }^{43}$ but Kilmuir's speech was, it is said, drafted by Lord Parker of Waddington. ${ }^{44}$ With his abundant common sense and absence of unction Kilmuir found no fun in the sophisticated paradoxes and dilemmas engendered by reflections on legal concepts. Perhaps this is why in his eight years he sat in only 24 appeals. But in his informal moments he was zealous in his attendance at soirées organised by glamorous, intelligent and patrician society hostesses: "To the Celt, looking in from the outside darkness through the windows which framed the splendour of English political life, there was something

42. At p. 169 .

43. [1961] A.C. 290.

44. Heuston, p.175 n.8. 
very satisfying about being on first name terms with the Cecils and the Cavendishes." 45

It is a special pleasure for this reviewer to note that members of the Francis Bacon Society still recollect with gratitude Kilmuir's contribution at the dinner in Gray's Inn Hall in 1961 held to commemorate the fourth centenary of Francis Bacon's birth. ${ }^{46}$ The Lord Chancellor proposed the principal toast, "The Immortal Memory of Francis Bacon", and in his speech remarked how "No Lord Chancellor can look over the arches of the 1,366 years of his office ... without seeing the mental power of Bacon stand out from among us like a sudden mountain peak in a range of grass covered hills." Later he considered why it was that Bacon had so persistently importuned Burghley and James for office and, in doing so, gave a signal of his own motivation in politics: "I think the explanation is that those of us who have the political virus, who have the love for what $F$. S. Oliver called the endless adventure of the government of men, must always be considering not only our political ideals and aims but the means of putting some of them into effect. In Oliver's words our eyes are not always fixed on the millenium or on the end of our noses but some way between."

Whereas Simonds' estate had been sworn for probate at $£ 305,279$, the largest sum left by any Lord Chancellor since Eldon, Kilmuir modestly, perhaps cannily, left a mere twenty odd thousand.

Viscount Dilhorne, Reginald Manningham-Buller, was not a humble man. He was irritable and insensitive to the feelings and failings of others - qualities which are sometimes to be found in mediocre men who have reached, as they suppose, exalted positions. Lord Devlin's assessment in Easing the Passing (1985) on the Bodkin Adams case is now notorious. To Devlin, "What was almost unique about him and makes his career so fascinating" is that he achieved what he did "by making himself disagreeable." did not suffer fools gladly - but then why should one?"48 Goddard himself would not have been unhappy to see Manningham-Buller succeed him as Lord Chicf Justice, but the latter was, apparently, "an unsaleable product". 49

But even if Dilhorne did turn arrogance into an art form, he was possessed of extraordinary energy and loyalty to his party and was genuinely motivated to be of honest service to the state. As Attorney-General he gave clear and emphatic advice and so was highly regarded in government circles. Some said he was the best Law Officer the Conservative Party had produced since the first Viscount Hailsham. As Lord Chancellor he was the first to give a woman her chance when promoting Elizabeth Lane to the County Court Bench. He also advocated wider membership of the Judicial Committee of the Privy Council, with the result that judges from

45. Heuston, pp.162-163.

46. The proceedings are reported in Baconiana LXV (March 1962).

47. Easing the Passing, p.39.

48. Heuston, p. 189.

49. Heuston, p.193. 
Nigeria and the Antipodes were appointed. Though in his two years on the Woolsack he presided in only seven appeals, as Law Lord in the period 1969-1980 he sat in more than 200. His judgments "will not figure in any anthology of English prose" 50 but in quality they are every bit as 'legalistic' as those of others whose sole preoccupation has been the law albeit with a tendency to become mere digests. But then his professional pedigree was impeccable. Coke, some of whose less pleasant foibles Dilhorne shared, was one of his ancestors. Sir Francis Buller, ${ }^{51}$ who had become a Judge of the King's Bench at 32 and whose Buller's Trials at Nisi Prius achieved seven editions, was another.

By birth Dilhorne was a Buckinghamshire man. Later he resided at Greens Norton Court, near Towcester, in Northamptonshire. His family was of the 'hunting, shooting and fishing' variety and his father had been MP for Kettering. His "was not an intellectual household". ${ }^{2}$ The Manningham-Buller Cup, which Dilhorne had presented to his constituency Conservative Clubs in 1952, remains the subject of fierce competition within the ten Clubs still struggling to secure that particular laurel in those 'manly' pastimes - snooker, darts, dominoes and cribbage. $^{53}$ It was entirely appropriate that Dilhorne, whom Macmillan had determined should have his "turn before the end", ${ }^{54}$ should have died so suddenly in 1980 after a day on a Scottish hillside.

As Dilhorne was to Coke so was Gardiner to Bacon. ${ }^{55}$ Gardiner represented cosmopolitan charm and reforming passion. His "appearance and conversation were unmistakenly those of someone born before the first World War into the English upper classes." 56 At Oxford he had been editor of Isis and later, despite a rapidly increasing practice at the Bar, he trod the boards with the Windsor Strollers and the Canterbury Old Stagers. In the 'sixties his sole recreation was "first-nighting", followed by a late dinner in Soho. He also assiduously attended meetings dedicated to good causes. He wrote learned articles and case notes in the Lam Quarterly Reviem and other journals and so continued a tradition among judges which Denning had nurtured, much to Jowitt's horror, with his Hamlyn Lectures. ${ }^{57}$ In the fifties he was very fashionable and played his part in several cases which captured the nation's attention - the libels involving Evelyn Waugh and "the singer Liberace" (sic), the ETU case, which concerned Communist infiltration of that union, and, of course, the Lady Chatterley's Lover case. Gardiner was a

50. Heuston, p.199.

51. 1746-1800; see Simpson, supra n.5, pp.87-89. Buller also seemingly shared Coke's characteristics.

52. Heuston, p. 184

53. Buckingham Advertiser, 7th August 1987.

54. Letter to Kilmuir, 15th July 1962: Heuston, p.177.

55. Obviously this remark is intended to be complimentary. It is sad that even a Lord Chancellor and a former Master of the Rolls should have yielded to the conventional Campbell/Macaulay/Abbott view of Bacon's fall thereby ignoring all research in the period since Spedding: see Howe [1987] A.C. 417, at p.431 (Bacon "a greater moralist perhaps in theory than in practice") and Lord Denning, Landmarks in the Law (1984), pp.32-34.

56. Heuston, p.207.

57. Freedom Under the Law (1949). 
formidable and charismatic figure with the actor's gift, so well practised by Alec Guinness, of conveying intense emotion with a minimum of gesture. He was elevated to the Woolsack directly from the Bar, confuting the arguably stronger claims of Soskice and Donovan. His political experience had been forged in the folds of the Haldane and Fabian Societies, those pot-pourris of the airy-fairy and beer and sandwiches. To give him political experience Wilson had recommended a Life Peerage in December 1963, though when, the following year, the Woolsack was offered he had still only met Gardiner on three occasions. To Crossman, Gardiner was "utterly remote from the realities of politics". ${ }^{58}$ But with Wilson's support he vigorously set about determining "how large and effective the role of the Lord Chancellor in the field of law reform could be made to be"59 - with what majestic results the world knows. As Lord Hailsham has recorded ${ }^{60}$ his "chief monument", amongst his vast schemes for reform, will doubtless be the creation of the Law Commissions; and so it was through Gardiner's hands that one of Bacon's own grand ambitions for the reform of "snaring" laws, conceived some 350 years before, was finally realised.

Any biographer - or reviewer of biographies - must surmount certain procedural and substantive hurdles of which the ordinary reader will probably be insensible. The Gradgrinds of this world who want nothing but facts are easily satisfied, save that even here the biographer may be faced with apparently insoluble puzzles. For example, the records show that Kilmuir was born at 60 , Morningside Drive, Edinburgh. A pilgrimage to that place reveals that there is no No. 60. Are the records wrong? Was the house pulled down? Have the houses been renumbered? Or again, on a similar jaunt to Withyham to view Kilmuir's commemorative plaque on the North Wall of the Church of St Michael and All Angels, our biographer finds, confounding all the public records, that Kilmuir was Lord Chancellor from 1953 not 1954; a stonemason's error, a quirk of memory in the family or what? To rely on the evidence of observation could prove fatal to credibility and even the photograph of the plaque pronounced a forgery. There are other sorts of evidence which must be duly sifted and weighed. The memoirs of contemporaries, a rich source for anecdote and appraisal, may be faulty through the fallibilities of memory, bias, sycophancy or spleen. What the soldier said is not evidence after all. What does one do with all those state papers accumulating dust but recording Simon's years of inactivity at the Foreign Office? How does one avoid the biographer's curse, Macaulay's Lues Bosmelliana or disease of admiration? And what of the 'warts' in a man's character when he still lives or when what one says may offend the family? And then there are the publishers who cage the work of

58. Heuston, p.218 n.2.

59. Heuston, p.226.

60 Supra n.4. 
twenty years, and six men's lives, with word limits in the name of economic restraint and profit margins. Within those parameters how is the relative value of 'lives' to be measured? Does one titillate with famous trials or diminish the significance of a man's life in the law to capture a wider, perhaps more selective, collective imagination? As Historian does one set the subject against a backcloth of 'problems' or 'periods'?

Given all this, it would be too facile to dismiss the present volume as a series of rather slight sketches "hardly worthy of its predecessors". ${ }^{61}$ True, a butcher's knife rather than a proof reader's pencil could well be taken to those numerous irritating typographical errors in the text. For lawyers the extra "space" mysteriously made available to Professor Heuston by the publishers ${ }^{62}$ might have been employed to give a more prominent sense of chiaroscuro to the legal 'philosophies' of these Lord Chancellors or, if their lives did not warrant it, at least a separate section on the leading judgments as in the earlier volume. Occasionally Professor Heuston might have considered gentle pruning. If, for example, Lord Widmerpool in Powell's $A$ Dance to the Music of Time was not based on the character of Dilhorne why flaccidly instruct the reader that "casual resemblances of this kind often occur in novels"? ${ }^{63}$ Perhaps it adds little to the profundity of even personal history to say that Simonds' younger son, sadly killed at Arnhem, had "Before his death ... married Barbara (Robinson), widow of FO A. J. Willock (who married thirdly Dr Angus McPherson)." ${ }^{\text {"64 }}$ And what does the discerning reader make of the assertion that "In appearance and manner Jowitt was a great Lord Chancellor"? 65

But these are little carping things often a matter of judgment and not to be taken too seriously. For this volume has all the qualities which made its predecessor such effortless reading - balance, scholarship, eloquence and humour - all things of which Campbell devotees would approve. In the balloting of contemporaries, Lord Pearce, it is worth saying, comes over particularly well not least for his delicious cartoon of the Law Lords in Woods v. Duncan, ${ }^{66}$ before whom he had argued for the respondents and whose roll had recently been increased by the addition of Simonds: "They looked like a Rembrandt, so old and remote and learned, and Gavin (though silent, while Simon, presiding, talked 'clever' stuff) looked like some superimposed figure painted in by Franz Hals - so eager and vital and robust and down to earth." 67

\section{Ibid..}

62. Sec Preface.

63. Heuston, p. 185.

64. Heuston, pp.142-143.

65. Heuston, p.126.

66. [1946] A.C. 401.

67. To Heuston, quoted p.146. The 'Rembrandt' figures were Viscount Simon and Lords Russell, Macmillan and Porter. 
There is much here, in the introduction and the 'lives', to inform and stimulate reflection upon the office of Lord Chancellor which in our unwritten constitution so cocks a snook at the doctrine of the separation of powers. No formal qualifications are necessary for the office save capacity to swear the oath of allegiance and the official oath and yet our present day Lord Chancellors are required to head the judiciary, serve as Speaker in the House of Lords and cabinet member as well as minister in charge of a large government department. Things seemed simpler in the old days for this first subject of the realm after the Archbishop of Canterbury. He did not then even have to be a lawyer. Heuston cites the case of Chancellor Booth in 1473 who was formerly Bishop of Durham but who, as Lord Chancellor, was so incompetent "doing nothing" that he was packed off to the Archbishopric at York 10 months on. At least a grudging mention might have been given to Lord Keeper Williams, formerly Dean of Westminster and part architect of Bacon's fall from grace, who also had no legal training but who fared much better than Booth. He stayed the course for four years, the last ecclesiastic to hold the Great Seal, before being bundled back to his Bishopric at Lincoln. ${ }^{68}$

An interesting question which Heuston raises but does not fully explore is the origin and fortune over the centuries of the concept that the Lord Chancellor is the 'Keeper of the King's Conscience'. We still say that he is, though two Lord Chancellors have said that the phrase is now meaningless. ${ }^{69}$ One possibility is that the idea originates from the ecclesiastical character of the mediaeval Chancellors and the role of the early incumbents as Chaplain to the King. Presumably, then, the concept ceased to be meaningful with Williams' fall in 1625; in which case it is surprising to find that it lingered on for three more centuries. Another is that the phrase relates to the Chancellor's equitable jurisdiction in the Court of Chancery, where the King's conscience was dispensed rather than his law. Neither theory squares with the diverse functions of the Lord Chancellor who 'kept' the Great Seal and the King's conscience. A third possibility, which is consistent with the duties of Lord Chancellors in different ages, is that the Chancellor was a perhaps the - principal professional and personal adviser of the Crown, a keeper of Seals but also of secrets and so of consciences. In this role he might even act as Prime Minister as Clarendon did, though the last to do so. The Chancellor's oath sworn as late as Stuart times reflects this idea in that he was required "truly to counsel the King and his counsel to conceal and keep."70 Nowadays the Lord Chancellor is required to swear an oath of allegiance, a judicial oath (which incorporates aspects of the old Lord Chancellor's oath) and, on being admitted to the Privy Council, a further oath in which the Privy Counsellor swears to be a

68. 16 years on Williams was also appointed Archbishop of York and so likewise eventually took only one formal step down the league Table of Precedence. Laud was then under impeachment in the Tower and so Williams was placed, de facto, at the head of the Church of England.

69. Sec Heuston, p.5 n.7 (Lord Hailsham and Viscount Simon). 
"true and faithful Servant unto the Queen's Majesty" and is enjoined to "faithfully and truly declare your mind and opinion according to your Heart and Conscience; and will keep secret all Matters committed and revealed unto you." ${ }^{71}$ So in this last oath we have the final vestige of the Chancellor's ancient role of one who, above others, advised the king in his need and kept those personal and state secrets entrusted to him.

Such obscurantist by-ways apart, there are other insights which Heuston provides interstitially in his roll call of these "pale unsatisfied ones" who stood "on the highest pavement of the stair". Some painstaking cypher work plus casual surveillance will disclose a good deal for those who have set their minds upon the ascent to that place. What follows may serve, even in play, as a suitable glass.

To begin at the embryo stage. Despite the predictions of astrologers there is no especially propitious month to signal the birth of a Lord Chancellor. A genius like Bacon might well run true to form in the sign of Aquarius but none of Heuston's 18 Chancellors had that benefit and only two - Halsbury and Maugham - were covenanted under the favourable signs of Virgo and Libra. The rest are evenly scattered in ones and twos across the Zodiac chart save that the latter part of February and most of March has proved moderately promising in Pisces which has proferred its protective cloak and, if the astrologers are right, much imagination but also some emotional instability on four incumbents. ${ }^{72}$ Birth at the beginning or end of a month would seem auspicious. Dilhorne, Halsbury, Herschell and Loreburn entered this world in the first three days; six of the eighteen on the 28th, 29 th or 30th. ${ }^{73}$ Naturally, these omens are for ambitious parents only. It is for Providence to explain the birth-death sequence of Simonds and Herschell who were born and died on the same date though in different months. ${ }^{74}$

It is essential for the aspirant to set his sights on Oxford. All the subjects of this volume were there, at what are generally reckoned to be the 'better' Colleges, and seven of the 12 in the earlier volume. Of the remaining five, poor Cambridge has only managed two (Maugham and Caldecote) along with Edinburgh (Finlay and Haldane). Herschell read Classics at University College, London. Hailsham spent his formative years on the family sugar estate in British Guiana. Once at Oxford, it is clear that academic prowess is not a condition precedent for the Woolsack. The statutory mediocrity of the 2:2 might have proved an irritation to Kilmuir and Dilhorne, who obtained Thirds, and Gardiner who was placed into the Fourth Class. Equally, neither does brilliance preclude, for Jowitt obtained a First in Law as did Simon and Simonds in Greats. If examination pressures lead to what some students call "brain fag", the aspirant should not be unduly perturbed; even

70. See, e.g., Judge Jenkins' Plea to the Commons, 14th February 1647 in Terry, Fudge Fenkins (1929), pp.152-153.

71. These Oaths are usefully reproduced in Heuston's Appendix of Documents.

72. Cave, Caldecote, Hailsham and Simon.

73. Haldane, Hailsham, Simon, Simonds, Kilmuir and Gardiner.

74. Finlay and Jowitt miss the sequence by only one day. 
Buckmaster with his Second suffered from it. His brain, he said, "simply refused to perform its functions". ${ }^{75}$ When faced with the choice of an Inn, Gray's should almost certainly be avoided. Seemingly only three Lord Chancellors in history, Bacon, Birkenhead and Kilmuir, have ornamented its walks. By all means enrol at Inner or Lincoln's, the choice of 13 of Heuston's subjects.

A political baptism is not essential, as Simonds' and Gardiner's lives amply demonstrate, but without it, as has been seen, a newly appointed Lord Chancellor is apt to be considered, paradoxically, an "innocent" ${ }^{76}$ - which though a divine virtue is apt to be construed as synonymous with being politically inept. However, a man's esteem at the Bar is likely to rise in inverse proportion to his political commitment; Lord Goddard, for example, considered Kilmuir an ill-advised choice because too 'political' in his approach to legal matters. Whichever way the stairway leads physical stamina and application are essential. Kilmuir and Dilhorne were outstanding in this regard. ${ }^{77}$ Whatever his critics may say, Dilhorne cannot be faulted in his appetite for work whether as Lord Chancellor or in his 11 taxing years as Solicitor and Attorney-General. An obituary notice in The Times reported: "It was not unusual to find him, when all had gone home, working in the small hours in his room just off the central lobby, a pipe firmly in his mouth, alone, and unmoved by the hour of the night or the fatigues of the day in court and in the House, that would have exhausted a less robust man." 78 Not that the aspirant should eschew sports and pastimes. Dilhorne only just missed a Blue in rowing; Jowitt was a connoisseur of cricket, pigs and sheep and the arts; Gardiner of good causes and the theatre; Simon of ice-skating and golf. It is a good thing to have a plan for the top. Ideally it should not be published for overt "careerism" may be regarded as vulgar. Kilmuir determined to take Silk in his thirties, to become a cabinet minister in his forties and reach the apotheosis of the legal profession in his fifties - and, of course, he did it. Simon, who really did do everything he needed to do by the age of forty, knew well what he was about when he refused the Woolsack in 1911 for that would have ended his political dreams.

As has been noted, once on the Woolsack it might be considered precocious to preside over too many appeals. Whether from an undue regard for the doctrine of the separation of powers or simply from the pressure of other work, Jowitt, Simonds, Kilmuir, Dilhorne and Gardiner were impeccable in this respect. And there are clear risks in other than a conservative approach to the judicial function. Social therapy, what Viscount Dilhorne referred to as "adjusting the common law to what are thought to be the social norms of the time"79 and Bacon characterised as the "idols of the tribe", is to be totally shunned in a judicial capacity. But

75. Heuston, supra n.3, p.248.

76. Kilmuir's description of Simonds, Heuston p.149; and $c f$. Crossman on Gardiner, supra n.58.

77. See Heuston, pp.164, 188.

78. Heuston, p.188; $f$. Carlyle: "Genius" means "transcendent capacity for taking trouble, first of all" (Frederick the Great, Book IV, Ch.3).

79. Broom v. Cassell E Co. Lid. [1972] A.C. 1027, 1107. 
politically by all means extol the virtues of reform for at least biographers will see in that, perhaps quite rightly, a mark of greatness.

A majestic presence and ease of manner coupled, naturally, with "enormous dignity" or gravitas may be helpful, as in Jowitt's case; and two friends of the writer have independently remarked that Kilmuir and Gardiner are to be especially remembered for the laser-like luminosity of their eyes. 'Niceness', characterised by Lord Gardiner, is not an obvious prerequisite. Dilhorne needs no further comment but even Simonds did not take kindly to being contradicted and "he was too apt to interpret opposition as an insult to himself or the office which he held." Simon could be "elaborately polite" to juniors who made acceptable suggestions and to the "children of the upper classes who could not be his rivals" but he could also be "blisteringly rude in public to those whom he regarded as his inferiors." 81 All this, however, is to be cultivated in the name of 'character'. Without it one is apt to be seen, like Gardiner and perhaps Jowitt, as overly "detached" and so "unapproachable". 'Political' Lord Chanccllors of an earlier generation seem to have nurtured the art of flattery to a high degree. Some of Simon's utterances could have been spun at the court of the first Elizabeth. So when Chamberlain proposed to fly to Munich to meet Hitler in September 1938 Sir Thomas Inskip, later himself Lord Chancellor for eight months, in cabinet recorded that "John Simon finished by his usual shower of compliments to P.M. ... they give an impression of soapiness and flattery ... 'Brilliant' ... his absence 'grievous' even for 48 hours. If he came back with seeds of peace with honour 'a remarkable achievement' and so on.",82

Provided constitutionally robust in early middle age, the aspirant should not concern himself that the rigours of office will shorten his earthly span as compared with other men. The fact is that Lord Chancellors do seem to live a little longer than most. From Halsbury to Caldecote their average score was 76 years and 10 months; from Simon to Dilhorne, 77 years and one month. Halsbury was 'out' only two years short of his century and five others in the period reached the 80 s and 90 s. Only Birkenhead and Herschell did not reach conventional retiring age. For some reason, these days Lord Chancellors prefer cremation. ${ }^{83}$

The writer must issue one final and very serious warning. Lord Chancellors out of office tend to frustration, disenchantment, even bitterness. Simon thought himself a failure never to have become Prime Minister. To his sister Jowitt, out of office, wrote: "I must confess just at the moment I feel that the bottom has quite fallen out of my market. I've given myself completely to my office. It's been my life and enshrines all my interests ... I feel a lost soul just for the time being ... It all sounds like the lament of Job from the bottom of the pit ... though I am called

80. Heuston, p. 150 .

81. Heuston, p.40

82. Heuston, pp.52-53.

83. Loreburn and Buckmaster began the fashion which was revived and continued successively from Simon to Kilmuir. 
upon to surrender the Seals no one can call upon me to surrender the memories." ${ }^{84}$ Simonds was an embittered man when he was forced to surrender the Seals to Maxwell Fyfe, "one nearly 20 years his junior for whose attainments as a lawyer he had little respect." ${ }^{185}$ Eight years on the same fate befell Kilmuir who was equally resentful. There is something, then, in Rosebery's warning that it is better for a man to aim at being Lord Chief Justice since, though the position of Lord Chancellor is dignified while it lasts, it does not last longer than a change of government, an ex-Lord Chancellor being merely "a shabby old gentleman with $£ 5,000$ a year." ${ }^{, 86}$ So a sense of proportion and detachment are indispensible qualities in readiness for this moment of personal crisis. Though the Office carries "whispers of immortality", the aspirant must ever carry with him the simple thought that

"In a moment there is time

For decisions and revisions which a moment will reverse"

and a measured palliative for undue self-importance of a kind which Prufrock also recognised:

"No! I am not Prince Hamlet, nor was meant to be;

Am an attendant Lord, one that will do

To swell a progress, start a scene or two,

Advise the Prince; no doubt an easy tool,

Deferential, glad to be of use,

Political, cautious, and meticulous;

Full of high sentence ..."

In Bacon's words in the essay Of Great Place, all rising is by a winding stair. It is a laborious climb beset with pains. The standing is slippery and the regress is either a fall or other eclipse which is "a melancholy thing". Despite its minor blemishes and its daunting price, Professor Heuston's second volume of Chancellors contains an abundance of riches not least, in spite of itself, the realisation that Plato's ghost had a point when, despite all those things "to perfection brought", he louder sang "What then?"

86. Heuston, p.5. 